\title{
MESIN PEMERAS KELAPA PARUT MENJADI SANTAN SISTEM ULIR TEKAN PENGGERAK MOTOR LISTRIK 1 HP
}

\author{
Abdul Syukur Alfauzi, Rofarsyam \\ Jurusan Teknik Mesin Politeknik Negeri Semarang \\ Jl. Praf. Sudarto S.H Tembalang, Semarang 50329
}

\begin{abstract}
The squeezing process of grated coconut into coconut milk, and the following process of making the milk into coconut oil, which is done by people living in rural areas, is until now still very traditional. They do it manually (by hands) so that they produce $7.2 \mathrm{~kg} / \mathrm{hour}$ grated coconut or 3.6 litres/hour thick coconut milk.

To effectify the process, the squeezing needs to be mechanized, using a grated coconut squeezer machine.

The machine is designed on the basis of Screw Press system with a 1/4 HP $1450 \mathrm{rpm}$ electric motor power using a pulley belt transmission and a gear box. The squeezer's force refers to coconuts aging between 341 and 413 days (hand squeezing force normally practised by coconut oil producers in rural areas).

This prototype of machine has the capacity of producing $53.2 \mathrm{~kg} / \mathrm{hour}$ grated coconut or 26.6 litres/hour thick coconut milk, which has similar quality (in colour, smell and texture) as that manually squeezed.
\end{abstract}

Keywords : grated coconut squeezer, coconut milk

\section{PENDAHULUAN}

Penggunaan minyak kelapa selain digunakan sebagai pengolah bahan makanan sehari-hari juga digunakan sebagai bahan baku industri non pangan, sehingga peluang usaha pada bidang ini sangat menjanjikan. Namun proses produksi minyak kelapa di derah pedesaan di Indonesia yang serupa kondisinya dengan desa-desa di kecamatan Musuk kabupaten Boyolali, kabupaten Demak, dan kabupaten Sragen masih dilakukan dengan cara tradisional, terutama dalam proses pemerasan kelapa parut menjadi santan kental, yaitu diperas dengan tangan atau diinjak-injak dengan kaki pada bak khusus sambil disirami dengan air secara perlahan, sehingga kapasitas yang dihasilkan hanya 7,2 kg/jam kelapa parut atau 3,6 liter/jam santan kental. Proses pemerasan tersebut dirasakan kurang efisien, oleh karena itu perlu perbaikan pemerasan secara mekanis, agar kapasitas santan kental persatuan waktu dapat ditingkatkan dan pada akhirnya berdampak pada pemanfaatan bahan baku (buah kelapa) yang ada menjadi optimal sehingga diharapkan dapat mendorong perkembangan industri dalam bentuk komoditi lain, seperti industri santan awet (santan instan), dan untuk meningkatkan peranan buah kelapa sebagai sumber pendapatan daerah sehingga dapat menarik para penanam modal sebagai bapak angkat.

Mekanisasi proses pemerasan tersebut perlu dilakukan karena proses pemerasan kelapa parut yang dilakukan dengan cara tradisional selain 
pemborosan waktu, tenaga, juga ditinjau dari segi kebersihan tidak memenuhi standar kesehatan.

Untuk memperbaiki proses pemerasan agar lebih efisien, yang dapat meningkatkan kapasitas dan memenuhi standar kesehatan, maka mesin pemeras kelapa parut dibuat dengan sistim ulir tekan (screw press) dan tenaga penggerak motor listrik.

\section{METODE PEMBUATAN}

\subsection{Langkah Desain}

a. Mengukur gaya peras tangan terhadap kelapa parut $\mathrm{F}(\mathrm{kg})$

Untuk mendapatkan besar $\mathrm{F}$ tersebut dengan metode ke-empat jari (jari telunjuk, tengah, manis dan jari kelingking) di masukkan pada lingkaran kawat yang dihubungkan dengan neraca pegas, kemudian ke-empat jari tersebut digerakkan sampai menekan pangkal telapak tangan, maka pada neraca pegas menunjukkan angka dalam $\mathrm{kg}$ yang merupakan besar $\mathrm{F}$ yang dimaksud. Hasil percobaan yang telah dilakukan besar gaya peras tangan rata-rata adalah $\mathrm{F}=15(\mathrm{~kg})$.

b. Mengetahui hubungan berat kelapa parut $\mathrm{W}(\mathrm{kg})$ dengan volume kelapa parut $\mathrm{V}\left(\mathrm{m}^{3}\right)$

Untuk mengukur hubungan $\mathrm{W}$ dengan $\mathrm{V}$, yaitu dengan jalan kelapa parut dipadatkan atau ditekan dalam sebuah bak. Kemudian untuk mengetahui berat maka kelapa parut tersebut ditimbang, dan untuk mengetahui volumenya dengan mengukur dimensi kelapa parut padat dalam bak. Hasil pengukuran yang dilakukan rata-rata $W \sim 1 \mathrm{~kg}$ sama dengan $\mathrm{V} \sim 0,05 \mathrm{~m}^{3}$.

$1(\mathrm{~kg})$ kelapa parut $\sim 0,05\left(\mathrm{~m}^{3}\right)$ kelapa parut

c. Menghitung diameter ulir tekan $\mathrm{D}_{2}(\mathrm{~m})$

Untuk menghitung $\mathrm{D}_{2}$ menggunakan rumus :

$\mathrm{P}=\mathrm{F} \cdot \mathrm{S} \cdot \eta$

$\mathrm{P}=$ daya dalam $(\operatorname{kgf} \mathrm{m} /$ det $=\mathrm{Hp})$, diinginkan $1 / 4 \mathrm{HP}, \eta=0,75$

$\mathrm{S}=$ kecepatan dalam meter per-detik $(\mathrm{m} /$ det $)$

$\mathrm{S}=\pi \cdot \mathrm{D}_{1} \cdot \mathrm{N}_{2}$, sehingga :

$\mathrm{P}=\mathrm{F} \cdot \pi \cdot \mathrm{D}_{2} \cdot \mathrm{N}_{2} \cdot \eta$

$\mathrm{N}_{2}$ =putaran ulir tekan dalam (rpm), diinginkan $10 \mathrm{rpm}$

$\mathrm{D}_{2}=\frac{\mathrm{P} \eta}{\mathrm{F} \pi \mathrm{N}_{2}}=\frac{184 \cdot 0,75}{879 \cdot 3,14 \cdot \frac{10}{60}}=0,30[\mathrm{~m}]$ 
d. Menghitung kapasitas $\mathrm{Q}(\mathrm{kg} / \mathrm{jam})$ atau $\left(\mathrm{m}^{3} / \mathrm{jam}\right)$

Untuk menghitung $Q$ menggunakan rumus :

$Q=A \cdot S$

$\mathrm{A}=$ luas penampang volume kelapa parut dalam silinder atau pada ulir tekan ( $\mathrm{m} 2)$ dan dengan menentukan diameter tabung D1 = 0,31 [m], maka

$\mathrm{A}=\pi / 4 .\left(\mathrm{D}_{1}^{2}-\mathrm{D}_{2}^{2}\right)$.

$\mathrm{Q}=\pi / 4 \cdot\left(\mathrm{D}_{1}{ }^{2}-\mathrm{D}_{2}{ }^{2}\right) \cdot \mathrm{S}=\pi / 4 \cdot\left(\mathrm{D}_{1}^{2}-\mathrm{D}_{2}{ }^{2}\right) \cdot \pi \cdot \mathrm{D}_{0} \cdot \mathrm{N}_{2}$

$\mathrm{Q}=\pi / 4 \cdot\left(0,31^{2}-0,3^{2}\right) \cdot \pi \cdot 0,305 \cdot 10 / 60$

$\mathrm{Q}=7,52 \cdot 10^{-4}\left(\mathrm{~m}^{3} /\right.$ det $)$

Sesuai dengan persamaan (1) didapat $1 \mathrm{~m}^{3}$ kelapa parut $~ 19,95 \mathrm{~kg}$ kelapa parut, sehingga :

$\mathrm{Q}=7,52.10-4.19,95=0,015(\mathrm{~kg} /$ det$)$, atau

$\mathrm{Q}=0,887$ (kg/menit), atau

$\mathrm{Q}=53,2(\mathrm{~kg} / \mathrm{jam})$

e. Putaran motor listrik yang akan digunakan $\mathrm{N}_{1}$

Untuk menghitung $\mathrm{N}_{1}$ dengan menentukan diameter puli $\mathrm{d}_{1}=150 \mathrm{~mm}$ (satu poros dengan gear box) dan $\mathrm{d}_{2}=500 \mathrm{~mm}$ (satu poros dengan ulir tekan) dan menggunakan rumus :

$$
\begin{aligned}
& \frac{\mathrm{N}_{2}}{\mathrm{~N}_{1}}=\frac{\mathrm{d}_{2}}{\mathrm{~d}_{1}} \\
& \frac{10}{\mathrm{~N}_{1}}=\frac{150}{500} \\
& \mathrm{~N}_{1}=33,333(\mathrm{rpm})
\end{aligned}
$$

Karena motor listrik di pasaran tidak ada yang mempunyai putaran 33,333 rpm maka diperlukan transmisi roda gigi/gear box $1: 40$ sehingga dipilih putaran motor listrik $1450 \mathrm{rpm}$.

\subsection{Langkah Pembuatan}

a. Pembuatan ulir tekan

Gambar 1 merupakan sketsa ulir tekan, pembuatan dimensi ulir tekan mengacu pada $Q=0,015 \mathrm{~kg} /$ det dari 3 kali proses pemerasan, sehingga waktu proses pemerasan adalah $\mathrm{t}=3$ detik, maka panjang ulir tekan $\mathrm{L}$ dihitung dengan persamaan :

$$
\begin{aligned}
\mathrm{L} & =\frac{\pi \mathrm{D}_{0} \mathrm{~N}_{2} \mathrm{t}}{60} \\
\mathrm{~L} & =\frac{\pi \cdot 0,305 \cdot 10 \cdot 3}{60}=0,478[\mathrm{~m}] \\
\mathrm{L} & =0,5(\mathrm{~m})
\end{aligned}
$$




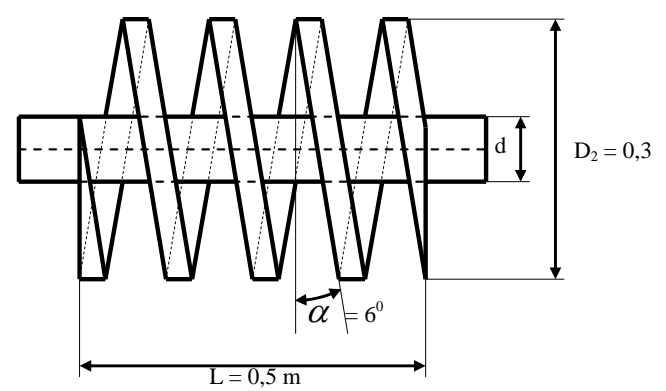

Gambar 1. Sketsa Ulir Tekan (Screw Press)

b. Pembuatan tabung

Gambar 2 adalah sketsa tabung ulir tekan yang dilengkapi dengan corong pemasukan dan lubang saluran santan. Dimensi tabung dibuat berdasarkan diameter $\mathrm{D}_{2}$ dan panjang $\mathrm{L}$ ulir tekan dengan memperhatikan ukuran kelapa parut. Karena kelonggaran antara ulir tekan terhadap dinding dalam tabung $0,5[\mathrm{~mm})$, maka diameter tabung $\mathrm{D}_{1}=0,31[\mathrm{~m}]$ dan panjangnya $\mathrm{L}=$ $0,5[\mathrm{~m}]$.

Pada dasar tabung sampai setengah diameternya dikonstruksi berlubang dengan ukur lubang mesh 200. Pada bagian atas di tengah tabung dibuat lubang tempat saluran masuk kelapa parut.

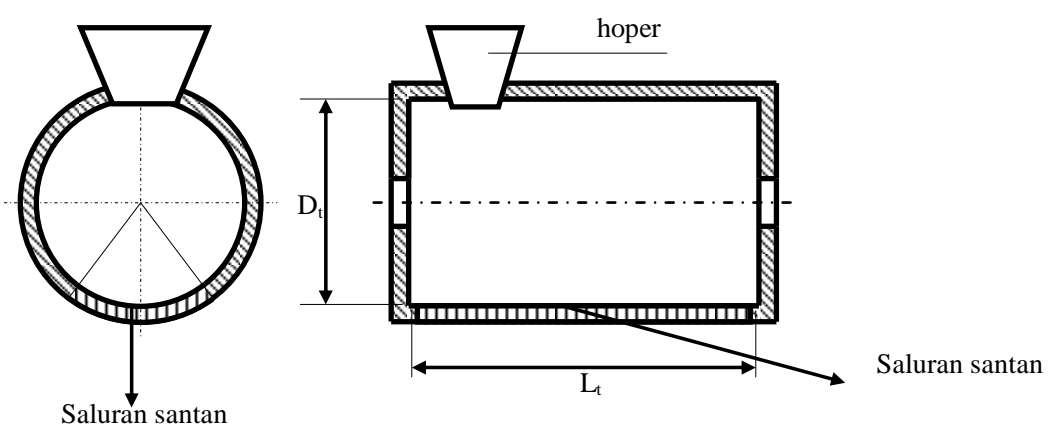

Gambar 2. Sketsa Tabung Silinder Dilengkapi Hoper dan Saluran Santan

c. Merakit mesin pemeras kelapa parut

Gambar 3 adalah sketsa transmisi putaran melalui dua tingkat transmisi yaitu roda gigi/gear box dan sabuk puli. Motor Listrik $1 / 4 \mathrm{Hp}$ putaran 1450 $(\mathrm{rpm})$, transmisi sabuk puli $\mathrm{D}_{1}=150[\mathrm{~mm}]$ dan $\mathrm{D}_{2}=500[\mathrm{~mm}]$, gear box 43,5 . Hasil rakitan mesin tersebut dapat dilihat pada gambar 4 . 


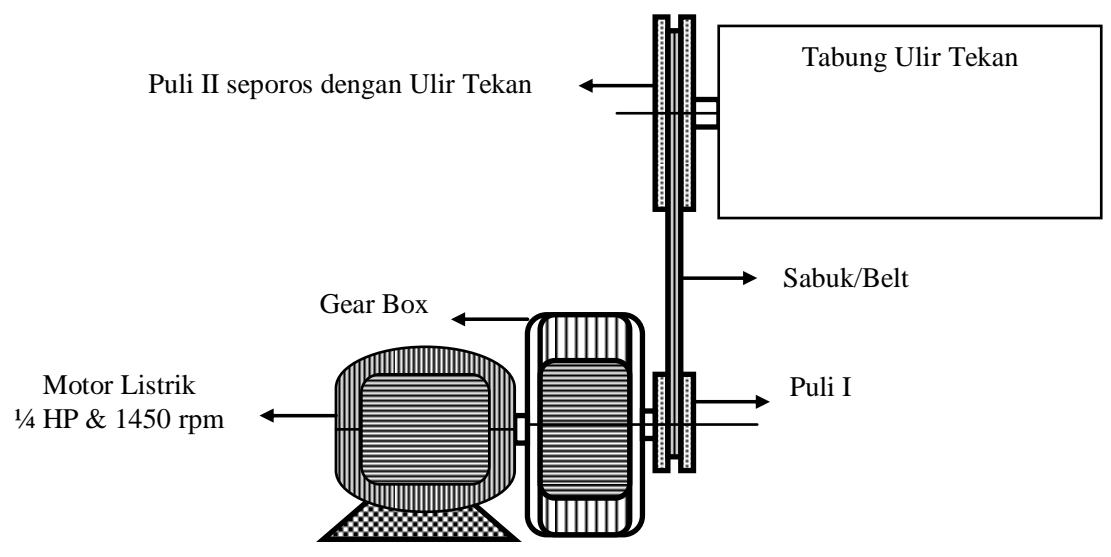

Gambar 3. Sketsa Dua Tingkat Transmisi Putaran (Gear Box dan Sabuk Puli)

\section{HASIL DAN PEMBAHASAN}

Gambar 4 merupakan gambar mesin peras kelapa parut yang dihasilkan, cara kerjanya sebagai berikut : Kelapa parut dimasukkan ke dalam alat melalui corong pemasukan bahan (1), selanjutnya diputar oleh ulir tekan (2) kearah tumpuan pemerasan (3), pintu pengeluaran ampas ditutup (4) beberapa detik sampai santannya sudah tidak mengalir melalui segmen pengeluaran santan (5), kemudian ampas dikeluarkan dengan membuka pintu buang ampas dan ditampung, kemudian dicampur lagi dengan air dan dimasukkan kembali sampai ampasnya kering (tidak mengandung santan).

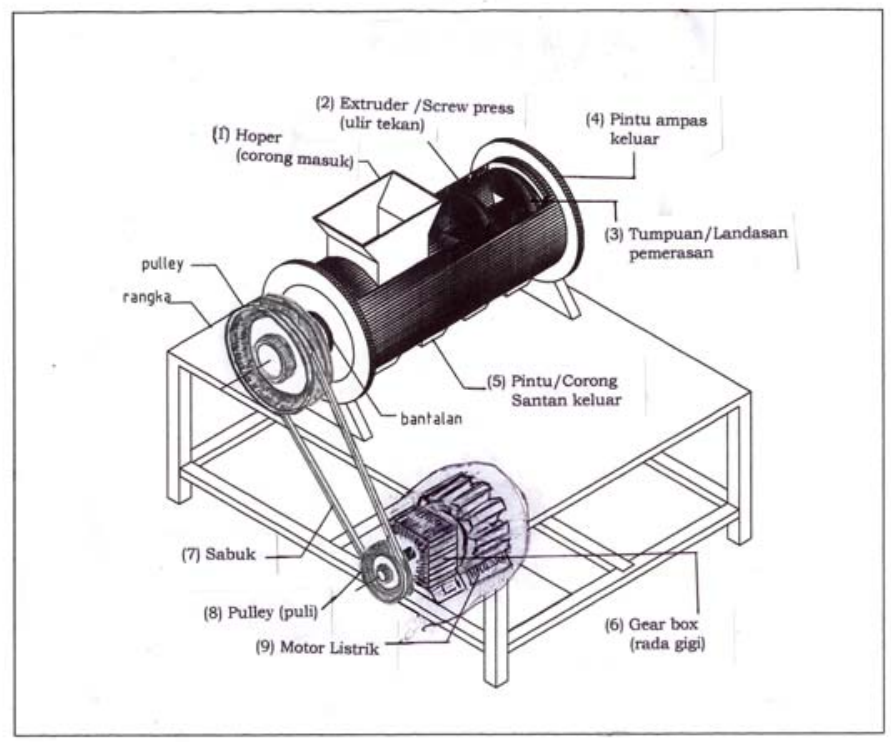

Gambar 4. Mesin Pemeras Kelapa Parut

TEKNOIN, Vol. 10, No. 4, Desember 2005, 249-256 
Proses pemerasan kelapa parut dengan ulir tekan membutuhkan putaran lambat, agar ulir mendorong kelapa parut dengan perlahan, sehingga proses pemerasan dapat berlangsung. Untuk mendapatkan putaran yang kecil pada ulir tekan, digunakan 2 (dua) tingkat transmisi, yaitu transmisi sabuk (belt) dan transmisi roda gigi (gear box).

- $\quad$ Transmisi gear box (6):

Putaran dan daya motor listrik ditransfer menggunakan roda gigi, dimana roda gigi I satu poros dengan motor listrik dengan daya $1 / 4 \mathrm{HP}$ dan putaran $\mathrm{N}=1450 \mathrm{rpm}$, sedangkan roda gigi II dengan putaran $\mathrm{N}_{1}=33,33 \mathrm{rpm}$. Pada poros roda gigi II diluar gear box dipasang puli berdiameter $\mathrm{d}_{1}=150[\mathrm{~mm}]$.

- $\quad$ Transmisi sabuk puli $(7,8)$ :

Putaran puli d1 memutar puli $\mathrm{d}_{2}=500[\mathrm{~mm}]$ seporos dengan ulir tekan berdeamter melalui sabuk, karena perbandingan diamter puli $d_{1}$ dan $d_{2}$, maka putaran ulir tekan menjadi $\mathrm{N}_{2}=10 \mathrm{rpm}$.

Hasil-hasil pengujian yang dicapai mesin pemeras kelapa parut rata-rata ditunjukkan pada tabel 1.

Tabel 1. Data Hasil Uji Proses Pemerasan Kelapa Parut Menjadi Santan Kental.

\begin{tabular}{|c|c|c|c|c|}
\hline $\begin{array}{c}\text { Mekanis } \\
\text { Pemerasan }\end{array}$ & $\begin{array}{c}\text { Berat Kelapa } \\
\text { Parut (kg) }\end{array}$ & $\begin{array}{c}\text { Volume } \\
\text { ( lt })\end{array}$ & $\begin{array}{c}\text { Berat Ampas } \\
\text { (kg) }\end{array}$ & $\begin{array}{c}\text { Waktu } \\
\text { (det) }\end{array}$ \\
\hline Dengan & 3 & 1.5 & 1.5 & 1500 \\
Tangan & 3 & 1.2 & 1.8 & 1620 \\
& 3 & 1.7 & 1.3 & 1800 \\
& 3 & 1.25 & 1.75 & 1200 \\
& 3 & 1.5 & 1.5 & 1380 \\
& 3 & 1.4 & 1.6 & 1800 \\
& 3 & 1.6 & 1.4 & 1200 \\
& 3 & 1.5 & 1.5 & 1500 \\
\hline Rata-rata & 3 & 1.5 & 1.5 & 1500 \\
\hline Dengan & 3 & 2.0 & 1.0 & 205 \\
Mesin & 3 & 1.8 & 1.2 & 200 \\
& 3 & 2.1 & 0.9 & 210 \\
& 3 & 2.3 & 0.7 & 195 \\
& 3 & 2.1 & 0.9 & 195 \\
& 3 & 1.7 & 1.3 & 205 \\
& 3 & 2.0 & 1.0 & 210 \\
& 3 & 1.8 & 1.2 & 200 \\
\hline Rata-rata & 3 & 2.0 & 1.0 & 203 \\
\hline
\end{tabular}


Mekanisme pengujian dilakukan terhadap $48 \mathrm{~kg}$ kelapa parut, $24 \mathrm{~kg}$ kelapa parut untuk proses pemerasan dengan tangan yang dilakukan 8 kali percobaan terhadap masing-masing $3 \mathrm{~kg}$ kelapa parut, dan $24 \mathrm{~kg}$ lainnya untuk proses pemerasan menggunakan mesin, juga dilakukan 8 kali pengujian tyerhadap masing-masing $3 \mathrm{~kg}$ kelapa parut.

Dari data tersebut menunjukkan bahwa kapasitas proses pemerasan dengan tangan adalah :

$$
\mathrm{Q}=\frac{3(\mathrm{~kg})}{1500(\text { detik })}=\frac{3(\mathrm{~kg})}{25(\text { menit })}=\frac{0,12(\mathrm{~kg})}{\text { menit }}
$$

Sehingga kapasitas tiap jam $Q=7,2[\mathrm{~kg} / \mathrm{jam}]$ sedangkan kapasitas pemerasan dengan mesin menunjukkan :

$$
\mathrm{Q}=\frac{3(\mathrm{~kg})}{203(\text { detik })}=\frac{3(\mathrm{~kg})}{3,38(\text { menit })}=\frac{0,887(\mathrm{~kg})}{\text { menit }}
$$

Sehingga kapasitas proses pemerasan kelapa parut menjadi santan kental menggunakan mesin adalah $\mathrm{Q}=53,2[\mathrm{~kg} / \mathrm{jam}]$.

Efisiensi mesin dibandingkan pemerasan dengan tangan adalah eff $=7,4 \mathrm{kali}$ lebih cepat, atau $740 \%$ terjadi peningkatan.

Kelebihan dan kekurangan mesin pemeras kelapa parut yang telah dihasilkan adalah :

a. Tingkat kebisingan sangat rendah dan getaran dapat diabaikan, kerena mesin ini dilengkapi dengan gear pengatur kecepatan yang berpelumas SAE20 sebagai penerus daya dari motor listrik.

b. Kenaikan suhu motor selama 2 jam sampai 4 jam dioperasikan, tidak terjadi kenaikan suhu motor.

c. Pengantar kelapa parut dalam ulir cukup baik, hanya saja sering tertahan dalam saluran pemasukan sebelum mencapai sepanjang ulir dan ampas yang keluar belum padat betul/belum kering, sehingga diperlukan pengulangan proses pemerasan sampai 3 kali untuk bahan yang sama.

d. Proses pemerasan berjalan dengan baik, santan dan ampas terpisah dengan baik, santan mengalir melalui segmen-segmen yang berukuran mesh 200, dengan panjang $15 \mathrm{~cm}$ sebanyak 10 buah segmen, dan serat ampas keluar melalui pintu ampas pada samping ujung tumpuan.

\section{SIMPULAN}

- $\quad$ Mesin pemeras kelapa parut sistim pres ulir (screw press) telah didesain dan dibuat modelnya, serta dapat digunakan dengan baik untuk memeras kelapa parut, dengan 53,2 kg kelapa parut per jam menghasilkan santan kental 26,67 liter/jam. 
- $\quad$ Mesin digerakkan oleh motor listrik $1 / 4 \mathrm{Hp}$ dengan putaran $1450 \mathrm{rpm}$

- Transmisi putaran menggunakan 2 tingkat transmisi, yaitu sabuk puli dan gear box.

- $\quad$ Peningkatan kapasitas dibandingkan dengan cara tradisional sebesar 7,4 kali lebih besar dengan kualitas hasil santan kental yang sama.

\section{PUSTAKA}

[1] Anonim, (1991) Teknologi Tepat Guna untuk Wanita di Pedesaan. Cetakan I Kantor Urusan Peranan Wanita bekerjasama dengan Unicef, Jakarta.

[2] Herman,A.S, Paradiyato, M.S. dan Sukawi F.X, (1997) Pemisahan Minyak dan Protein dari daging Kelap Cara Churning, Komunikasi No.186 BPK, Bogor.

[3] Hagenmaier,R.C.M.Cartet and K.F. Mattil, (1993) Aqueous Processing of Fresh Coconut for Recovery of oil and Coconut Skim Milk, Journal of Food Science, Singapore

[4] Puertollano, C.L.J.Banzon and K.H Steinkraus, (1990) Separation of the Oil and Protein Practions in Coconut (Coeos Nucifera LINN) by Fermentatio, Journal Of Agricultural and Chemestry, England.

[5] Sularso dan Kiyokatsu. S, (1999) Dasar Perencanaan dan Pemilihan Elemen Mesin, Cetakan ke II PT. Pradya Paramita, Jakarta.

[6] Sukrisno, Umar, (1994) Bagian-Bagian Merencana Mesin, Cetakan ke 4, Erlangka, Jakarta 